\title{
Impact of Intestinal Peptides on the Enteric Nervous System: Novel Approaches to Control Glucose Metabolism and Food Intake
}

\author{
Anne Abot ${ }^{1,2}$, Patrice D. Cani ${ }^{1,3}$ and Claude Knauf ${ }^{1,2 *}$ \\ ${ }^{1}$ NeuroMicrobiota, European Associated Laboratory (EAL), INSERM, Université catholique de Louvain (UCL), Toulouse, France, \\ 2INSERM U1220 Institut de Recherche en Santé Digestive (IRSD), CHU Purpan, Université Toulouse III Paul Sabatier, Paris, \\ France, ${ }^{3}$ Metabolism and Nutrition Research Group, Louvain Drug Research Institute (LDRI), WELBIO Walloon Excellence in Life \\ Sciences and BIOtechnology), Université catholique de Louvain (UCL), Brussels, Belgium
}

\section{OPEN ACCESS}

Edited by:

Gilles Mithieux,

Centre national de la recherche scientifique (CNRS), France

Reviewed by:

Virginie Tolle,

UMR 894 INSERM, France

Denis Richard,

Laval University, Canada

Xavier Fioramonti,

INRA UMR1286 Laboratoire

NutriNeuro, France

${ }^{*}$ Correspondence:

Claude Knauf

claude.knauf@inserm.fr

Specialty section:

This article was submitted to

Neuroendocrine Science,

a section of the journal

Frontiers in Endocrinology

Received: 26 March 2018

Accepted: 31 May 2018

Published: 22 June 2018

Citation:

Abot A, Cani PD and Knauf C (2018) Impact of Intestinal Peptides on

the Enteric Nervous System: Novel Approaches to Control Glucose Metabolism and Food Intake.

Front. Endocrinol. 9:328. doi: 10.3389/fendo.2018.00328
The gut is one of the most important sources of bioactive peptides in the body. In addition to their direct actions in the brain and/or peripheral tissues, the intestinal peptides can also have an impact on enteric nervous neurons. By modifying the endogenousproduction of these peptides, one may expect modify the "local" physiology such as glucose absorption, but also could have a "global" action via the gut-brain axis. Due to the various origins of gut peptides (i.e., nutrients, intestinal wall, gut microbiota) and the heterogeneity of enteric neurons population, the potential physiological parameters control by the interaction between the two partners are multiple. In this review, we will exclusively focus on the role of enteric nervous system as a potential target of gut peptides to control glucose metabolism and food intake. Potential therapeutic strategies based on per os administration of gut peptides to treat type 2 diabetes will be described.

Keywords: enteric nervous system, bioactive peptides, food intake, glucose metabolism, diabetes

\section{OVERVIEW OF THE ENTERIC NERVOUS SYSTEM (ENS)}

\section{Structural and Functional Organization of ENS}

The ENS, referred to as the "second brain," is composed of more than 600 million of neurons and glial cells in human. ENS runs along the gastrointestinal (GI) tract and is organized in two main plexuses. The submucosal plexus (or Meissner's plexus) lies in the submucosa of the intestinal wall and the myenteric plexus (or Auerbach's plexus) between the longitudinal and circular layers of the external musculature. Nerve fiber bundles connect the ganglia within a plexus and between the different plexi (1). Despite some differences in structural organization along the GI tract, the ENS controls main regulator of GI functions such as secretion, barrier function, and movement of fluid across the lining epithelium. It is also a key regulator of local blood flow, interaction with the immune and endocrine systems of the gut and intestinal motility (1).

Motility reflexes, mainly regulated by myenteric neurons, are necessary for the physiology of digestion and to modulate gastric emptying and GI transit time (propulsion by peristaltic waves, induced by migrating motor complex, and mixing the chyme by segmentation, in fed conditions, along the digestive tract) and favor nutrients absorption $(1,2)$. After food intake, mechanical distortion and modification of luminal chemistry induced by the chyme activate first networks of interconnected intrinsic sensory neurons IPANs (for intrinsic primary afferent neurons) and MEN (for mechanosensitive enteric neurons) (3-5). Action potentials generated are conducted 
to synaptic connections with IPANs to interneurons and to excitatory/inhibitory motoneurons that innervate the muscle (6). Each functional type of enteric neurons is defined by a neurochemical code (1). The ENS is mostly composed of choline acetyl transferase and neuronal nitric oxide synthase (nNOS) neurons that, respectively, stimulate and inhibit intestinal smooth muscle cells [for review, see Ref. (7)] (Figure 1).

This system is closely connected to the central nervous system (CNS) via sensory neurons that send afferent fibers conveying afferent nervous message. After hypothalamic integration, efferent sympathetic and parasympathetic pathways can modulate ENS functions such as motility, secretion, and circulation (1).

\section{Impact of Nutrients on ENS Activity}

Once nutrients have been absorbed or produced by metabolic activity, they are able to activate myenteric and/or submucosal neurons, encoding sensory stimuli, and therefore modulate ENS functions. In fact, enteric neurons express transporters and receptors which are involved in sensing of main nutrients such as SGLT-1 $\left(\mathrm{Na}^{+}-\mathrm{D}\right.$-glucose transporter) for glucose sensing, G-protein coupled receptor (GPR) 41 and 43 for short chain fatty acids (SCFAs) sensing, Pept2 (dipeptide transporter) and amino acid receptors activated by glutamate, glycine, or GABA for protein/peptide sensing [for review, see Ref. $(8,9)$ ].

\section{Physiopathological Aspect}

Alteration of nutrients and/or hormones sensing in the intestine are associated with aberrant hypothalamic responses that could lead to pathological states including T2D (10-12). For example, obese/diabetic mice and humans exhibit a decrease of nNOS expression in the digestive tract in correlation with an alteration of the ENS activity associated with intestinal hyper-contractility (12-16). In fact, physiopathological mechanism of diabetesinduced GI enteric neuropathy is complex and multifactorial. Autonomic neuropathy can affect both afferent and efferent connections between ENS and CNS $(10,12)$. High-fat diet ingestion induces damages and plastic changes in myenteric neurons that disrupt neural circuits, causing symptoms of dysmotility

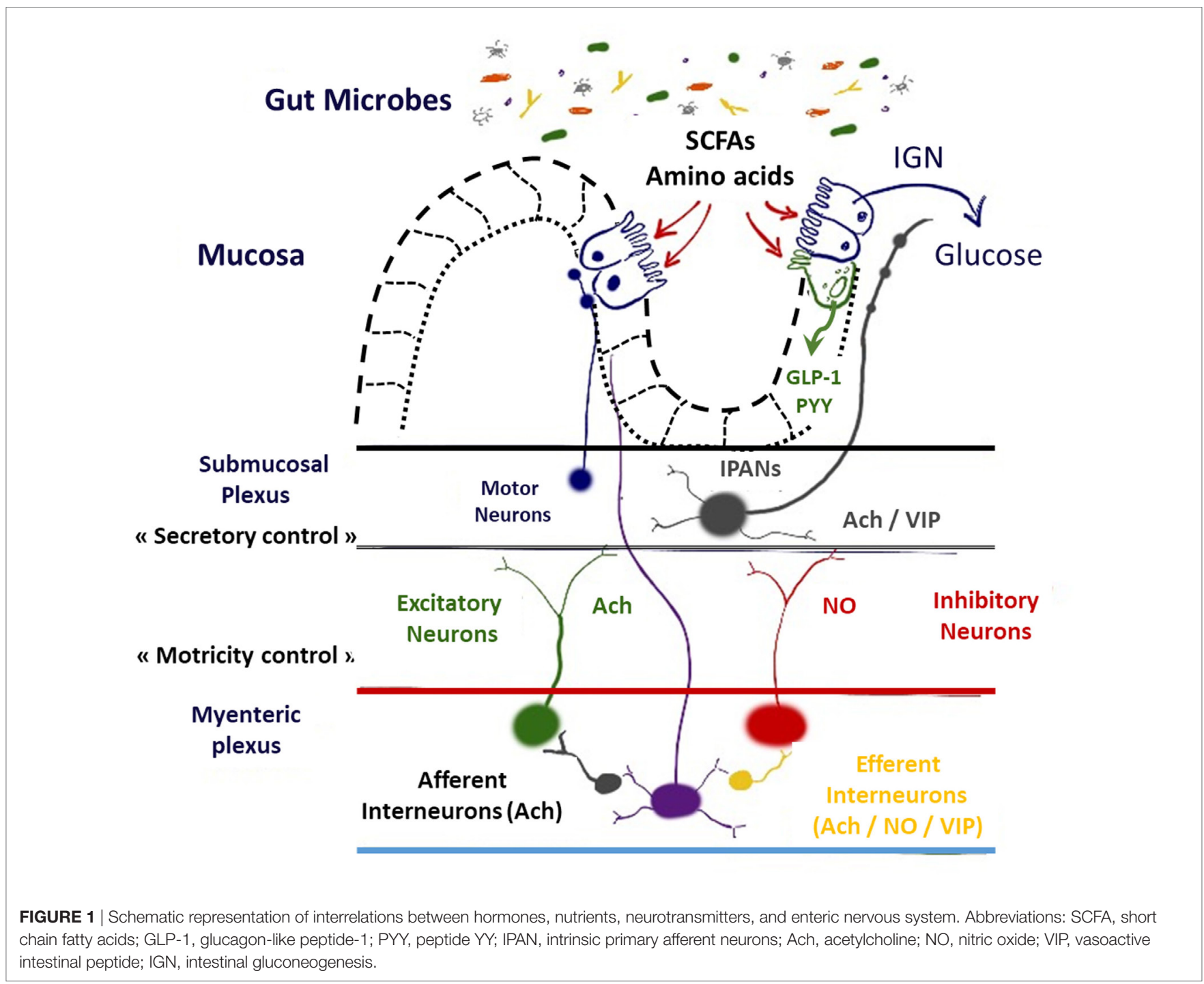


and correlates with neuropathy in the myenteric plexus of obese mice with symptoms of type 2 diabetes from duodenum to colon $(15,17)$. Indeed, high-fat diet ingestion during 12 weeks in mice induces duodenal hyper-contractility, accelerates colonic transit with enhanced neuronal cholinergic and serotoninergic excitation. This is a key feature of a later phase of obesity and is involved in altered ENS functions and abnormal duodenal absorption and colonic transit $(12,16,18)$.

\section{PEPTIDES MODULATING ENS NEURONS}

It is well known that numerous bioactive peptides from different origins are able to modulate ENS activity. They are present in the intestinal lumen and can reach the myenteric plexus to modulate the activity of ENS neurons $(12,16,19)$. Due to the great number of bioactive peptides able to control ENS (see Table 1), we decided to focus on some particular intestinal and bacterial peptides which present a potential therapeutic action on metabolic and feeding disorders.

\section{Intestinal Bioactive Peptides Peptide Hormone}

Among the specialized cell types localized to the intestinal epithelium, enteroendocrine cells (EECs) take part of the gut homeostasis and the efficiency of nutrient absorption through secretion of specialized peptide hormones that act in an

TABLE 1 | Hormones and neuropeptides implicated in the control of enteric nervous system (ENS).

\begin{tabular}{|c|c|c|c|c|c|}
\hline $\begin{array}{l}\text { Peptide } \\
\text { nature }\end{array}$ & Peptide & Impact on ENS functions & $\begin{array}{l}\text { Mechanism of action } \\
\text { on enteric neurons }\end{array}$ & Experimental model & Reference \\
\hline \multirow[t]{10}{*}{ Hormones } & $\begin{array}{l}\text { Proglucagon- } \\
\text { derived peptides }\end{array}$ & $\begin{array}{l}\text { Inhibition of the spontaneous } \\
\text { and evoked mechanical activity } \\
\text { of duodenum and colon } \\
\text { [glucagon-like peptide-1 (GLP-1)] }\end{array}$ & $\begin{array}{l}\text { Decrease of the excitatory } \\
\text { cholinergic neurotransmission } \\
\text { through presynaptic GLP-IRs } \\
\text { and modulation of NO release }\end{array}$ & Ex vivo conditions (mice) & Amato et al. (20) \\
\hline & & $\begin{array}{l}\text { Reduction of gastric motility } \\
\text { and gastric emptying (GLP-1) }\end{array}$ & $\begin{array}{l}\text { Exogenous GLP-1 acts in the } \\
\text { antral region, through neural } \\
\text { NO release }\end{array}$ & Ex vivo conditions (mice) & Rotondo et al. (21) \\
\hline & & $\begin{array}{l}\text { Reduction of gastric motility } \\
\text { and gastric emptying (GLP-2) }\end{array}$ & $\begin{array}{l}\text { Exogenous GLP-2 increases } \\
\text { locally GLP-2R expression } \\
\text { depending on fed conditions }\end{array}$ & $\begin{array}{l}\text { In vivo conditions (normal } \\
\text { and diabetic mice) }\end{array}$ & Rotondo et al. (21) \\
\hline & & $\begin{array}{l}\text { Neuroprotective effects } \\
\text { (GLP-1 and GLP-2) }\end{array}$ & $\begin{array}{l}\text { Improvement of myenteric } \\
\text { neurons survival in apoptose- } \\
\text { induced conditions }\end{array}$ & $\begin{array}{l}\text { In vitro conditions } \\
\text { (cultured myenteric neurons } \\
\text { from rat small intestine) }\end{array}$ & Voss et al. (22) \\
\hline & & $\begin{array}{l}\text { Reduction intestinal mucosal } \\
\text { inflammation (GLP-2) }\end{array}$ & $\begin{array}{l}\text { Activation of vasoactive intestinal } \\
\text { polypeptide (VIP) neurons of the } \\
\text { submucosal plexus, reduced } \\
\text { levels of inflammatory cytokines } \\
\text { (IFN- gamma. TNF-alpha. IL-Ibeta) } \\
\text { and inducible nitric oxide (NO) } \\
\text { synthase, with increased levels } \\
\text { of IL-10 }\end{array}$ & $\begin{array}{l}\text { In vivo conditions } \\
\text { (colitis rat model) }\end{array}$ & Sigalet et al. $(23,24)$ \\
\hline & & $\begin{array}{l}\text { Luminal infusion of cholecystokinin } \\
\text { (CCK) can produce segmenting } \\
\text { activity in duodenum and jejunum }\end{array}$ & $\begin{array}{l}\text { Involvement of CCK-1 and } \\
\text { CCK-2 receptors and serotoninergic } \\
\text { pathway in the mucosa }\end{array}$ & $\begin{array}{l}\text { Ex vivo conditions } \\
\text { (guinea pig small intestine) }\end{array}$ & Ellis et al. (25) \\
\hline & CCK & $\begin{array}{l}\text { Promotion of oxytocin-induced } \\
\text { contractions of longitudinal } \\
\text { muscle ships of duodenum }\end{array}$ & $\begin{array}{l}\text { Exogenous oxytocin favor the } \\
\text { duodenal CCK release from the } \\
\text { neurons of the myenteric plexus } \\
\text { to inhibit the muscle contraction }\end{array}$ & Ex vivo conditions (rats) & Lv et al. (26) \\
\hline & Ghrelin & $\begin{array}{l}\text { Peripheral administration of } \\
\text { exogenous ghrelin enhance } \\
\text { fasted motor activity of the } \\
\text { gastrointestinal tract }\end{array}$ & $\begin{array}{l}\text { Stimulation of enteric cholinergic } \\
\text { neurons }+ \text { possible role of } \\
\text { serotonin }\end{array}$ & $\begin{array}{l}\text { In vivo conditions (human: } \\
\text { antra duodenal manometry/ } \\
\text { record in freely moving } \\
\text { conscious rats) and } \\
\text { ex vivo conditions (for } \\
\text { mechanism, in mice) }\end{array}$ & $\begin{array}{l}\text { Human: Tract et al. (27)/ } \\
\text { rat: Fujino et al. (28) and } \\
\text { Taniguchi et al. (29)/ } \\
\text { mouse: Edholm et al. (30) } \\
\text { and Yang et al. (31) }\end{array}$ \\
\hline & Leptin & $\begin{array}{l}\text { Modulation of the activity of } \\
\text { enteric inhibitory and excitatory } \\
\text { neurons in proximal colon. }\end{array}$ & $\begin{array}{l}\text { Impact on enteric nitrergic } \\
\text { neurons and intrinsic primary } \\
\text { afferent neuron }\end{array}$ & $\begin{array}{l}\text { Ex vivo conditions } \\
\text { (rats) }\end{array}$ & Florian et al. (32) \\
\hline & Apelin & $\begin{array}{l}\text { Inhibition of duodenal } \\
\text { contractions }\end{array}$ & $\begin{array}{l}\text { Stimulation of the activity of } \\
\text { duodenal neuronal NO synthase } \\
\text { neurons }\end{array}$ & $\begin{array}{l}\text { Ex vivo conditions } \\
\text { (diabetic mice) }\end{array}$ & Foumel et al. (12) \\
\hline
\end{tabular}


TABLE 1 | Continued

\begin{tabular}{|c|c|c|c|c|c|}
\hline $\begin{array}{l}\text { Peptide } \\
\text { nature }\end{array}$ & Peptide & Impact on ENS functions & $\begin{array}{l}\text { Mechanism of action } \\
\text { on enteric neurons }\end{array}$ & Experimental model & Reference \\
\hline \multirow[t]{5}{*}{ Neuropeptides } & \multirow[t]{3}{*}{$\begin{array}{l}\text { Peptide } \\
\text { YY (PYY) }\end{array}$} & $\begin{array}{l}\text { Stimulation of propulsive } \\
\text { colonic motor function }\end{array}$ & $\begin{array}{l}\text { PYY inhibits basal and serotoninergic } \\
\text { and cholinergic on myenteric } \\
\text { neurons of the descending colon }\end{array}$ & $\begin{array}{l}\text { In vivo conditions } \\
\text { (microtransducer in } \\
\text { conscious mice model) }\end{array}$ & $\begin{array}{l}\text { Browning et al. (33) } \\
\text { and Wang et al. (34) }\end{array}$ \\
\hline & & $\begin{array}{l}\text { Stimulation gastric motor } \\
\text { activity }\end{array}$ & $\begin{array}{l}\text { Activation of enteric excitatory } \\
\text { neurons releasing acetylcholine } \\
\text { and tachykinins }\end{array}$ & In vivo conditions (mice) & Amato et al. (35) \\
\hline & & $\begin{array}{l}\text { Stimulation of both } \\
\text { enteric plexus }\end{array}$ & $\begin{array}{l}\text { PYY injected intraperitoneally } \\
\text { activates small intestinal enteric } \\
\text { neurons, both myenteric and } \\
\text { submucosal }\end{array}$ & In vivo conditions (rat) & Newman et al. (36) \\
\hline & $\begin{array}{l}\text { Neuropeptide } \\
\text { Y (NPY) }\end{array}$ & $\begin{array}{l}\text { Regulation of the inflammation } \\
\text { NPY severity and indirectly } \\
\text { gut motility }\end{array}$ & $\begin{array}{l}\text { Upregulation of NPY in ENS } \\
\text { and neuropeptide Y1 receptor }\end{array}$ & $\begin{array}{l}\text { In vivo conditions } \\
\text { (colitis mouse model) }\end{array}$ & $\begin{array}{l}\text { Wheway et al. (37)/ } \\
\text { Chandrasekharan } \\
\text { et al. }(38,39)\end{array}$ \\
\hline & Galanin & $\begin{array}{l}\text { Improvement of myenteric } \\
\text { neurons survival in apoptose- } \\
\text { induced conditions } \\
\text { Inhibition of duodenal } \\
\text { contractions }\end{array}$ & $\begin{array}{l}\text { Activation of nitrergic } \\
\text { myenteric neurons } \\
\text { Improvement of NO release } \\
\text { of enteric neurons }\end{array}$ & $\begin{array}{l}\text { In vitro (cultured myenteric } \\
\text { neurons from rat small } \\
\text { intestine) } \\
\text { Ex vivo conditions } \\
\text { (diabetic mice) }\end{array}$ & $\begin{array}{l}\text { Arciszewski et al. (40) } \\
\text { Abot et al. (16) }\end{array}$ \\
\hline
\end{tabular}

autocrine, paracrine, or endocrine manner and inform to nutrient availability (41). Different specialized EEC subtypes localized along the GI tract expressing distinct peptide families have been identified (42).

\section{Proglucagon-Derived Peptides (PGDPs)}

The PGDPs, notably glucagon-like peptide-1 (GLP-1) and GLP-2 are secreted in response to meal ingestion predominantly by EEC L-cells located along the GI tract $(43,44)$. This gut PGDPs exhibit robust actions controlling gut motility, but also food intake and glucose homeostasis by reducing postprandial glycemia $(45,46)$. GLP-1 exerts not only inhibitory effects on GI motility and participates to glucose absorption through vagal afferents and central nervous mechanisms but also a direct influence on the GI wall from duodenum to colon $(20,45,47)$ (Table 1). In fact, GLP-1 exerts an inhibitory effect on the spontaneous and evoked mechanical activity in the duodenum and colon of mice by acting in the enteric neurons, to decrease the excitatory cholinergic neurotransmission through presynaptic GLP-1Rs, which modulate NO release (20). Through this mechanism, GLP-1 is able to reduce gastric motility (21). GLP-2 treatment improves survival of myenteric neurons from adult rat small intestine through anti-inflammatory actions and increase population of vasoactive intestinal peptide (VIP)-expressing enteric neurons $(22,23,48)$. Thus, both GLP-1 and GLP-2 have neuroprotective effects (22).

\section{Cholecystokinin (CCK)}

Cholecystokinin is secreted by I-cells, principally localized in duodenum and proximal jejunum as well as enteric and CNS in response to feeding. CCK receptors (CCK-1 and CCK-2) are expressed in enteric neurons and involved in regulating nutrientinduced segmentation, with the participation of neuronal serotonergic signaling, activating both intrinsic and extrinsic primary afferent neurons to, respectively, initiate peristaltic and secretory reflexes and to transmit information to the CNS (25).
Thus, CCK is co-expressed in the neurons of the myenteric plexus in duodenum with oxytocin and participates to the inhibition of spontaneous contraction of the muscle strips, and this effect is abolished in response to lorglumide, a CCK1 receptor antagonist (26) (Table 1). This hormone is already under investigation in view of developing therapies for the treatment of obesity and type 2 diabetes (49).

\section{Ghrelin}

Ghrelin is produced in gastric endocrine cells and exerts its effects by interacting with ghrelin receptors (growth hormone secretagogue receptor 1a or GHSR1a) expressed within the GI enteric plexus $(30,50)$. Previous studies have demonstrated that ghrelin (endogenous or peripheral administration) promotes gastric and small intestinal motility, particularly fasted motor activity in experimental animal models but also in human (27-29). In fact, ghrelin stimulates motility in the small intestine of rats through intrinsic cholinergic neurons $(30,31)$ (Table 1).

\section{Apelin}

Apelin is a bioactive peptide implicated in the control of glucose metabolism by improving insulin sensitivity in normal and diabetic mice (51). Apelin is also secreted by enterocytes and is released in the luminal part of gut to favor glucose absorption (52).

\section{Neuropeptides}

Pancreatic Polypeptides (PP) and Related Peptides

Neuropeptide Y (NPY) and peptide YY (PYY) are structurally related peptides that are considered to mediate inhibitory actions on GI motility and secretion. In the ENS, double immunofluorescence demonstrates that subpopulations of the Y1 receptorpositive nerve cell bodies are immunopositive for NPY, VIP, and NOS (53). Intraperitoneal injection of PYY and NPY inhibit fecal pellet output per hour and inhibited high-amplitude distal colonic contractions and cholinergic-stimulated propulsive 
colonic motor function (34). They can increase cFOS activity in enteric neurons and exert powerful inhibitory effects on myenteric neurons of the descending colon $(33,36)$. In proximal part of the GI tract, exogenous PP stimulates mouse gastric motor activity, by activating gastric enteric excitatory neurons releasing acetylcholine (Ach) and tachykinins (35) (Table 1).

\section{Galanin}

Galanin is a neuropeptide largely expressed in the brain but also in ENS neurons (54). In the intestine, the majority of galanin effects are mediated by Gal-R1 predominantly expressed in ENS neurons and more particular in neurons that express Ach, nNOS, or VIP. More precisely, galanin is known to be a neuropeptide which exerts an inhibitory action on myenteric cholinergic neurons and enhance nitrergic neurons activity $(16,55)$. Galanin also exerts positive effect on survival of cultured porcine myenteric neurons (40) (Table 1).

\section{Bacterial Bioactive Peptides}

Microorganisms are able to synthesize a large number of metabolites which have beneficial or detrimental properties for human health. Interaction between gut microbiota and ENS in the control of gut motility and/or gut-brain axis is well documented. In fact, the gut microbiota produces bioactive molecules that act on enteric neurons to influence GI motility, and to modify the "gut-brain axis" by impacting on $\operatorname{IPAN}(56,57)$. However, the exact biochemical nature of bacterial molecules implicated in the ENS could be extremely large. Among these, nitrogen bearing molecules from gut microbiota such as amino acids, amino acids derivatives, and oligopeptides have received great attention. Gut microbiota influences the biosynthesis and the release of enteric neurotransmitter such as serotonin, a monoamine that participates to the control of GI motility (58). Nowadays, little is known concerning the implication of bacterial bioactive peptides in the control of metabolism via ENS. In fact, signal peptides from bacteria are formylated, and some studies have demonstrated that $N$-formyl peptides from bacterial origin can be sense by host cells (59). $N$-formyl peptides are detected by formyl peptide receptors which are G-protein-coupled receptors that act as chemosensing receptors. No direct link between $\mathrm{N}$-formyl peptides and ENS is described in the literature, but Cianciulli et al. have demonstrated that $N$-formyl-methionyl-leucyl-phenylalanine, synthetized by Escherichia coli and other Gram-negative bacteria, could release NO from chick embryo nerve cells (60).

\section{PEPTIDES/ENS AND GLUCOSE METABOLISM}

As explain earlier, numerous peptides are able to modulate the activity of ENS neurons to control the contraction of intestinal smooth muscle cells. How the control of intestinal contraction could have an impact on glucose metabolism? First, the fed state is characterized by the presence of segmental waves in the proximal part of the intestine which favor glucose absorption. In fact, a positive correlation exists between intestinal contraction and glucose absorption (2). Second, the duodenal contraction can be detected by the hypothalamus via an afferent nervous signal (12). Consequently, the increase of duodenal contraction provokes a drastic decrease of hypothalamic NO release, and then decrease glucose entry in tissue (16). This information suggests that intestinal peptide, such as apelin (12), could modulate the "ENS-smooth muscle" couple to favor glucose absorption at the beginning of food intake (12). At the opposite, a high level of apelin can decrease duodenal contraction to block glucose absorption, and then to increase the release of hypothalamic NO to favor glucose entry in muscle (12). Here, this last result supposes that intestinal peptides could have an opposite effect at the end of food intake and/or digestion to limit the level of plasma glucose in the whole body.

During metabolic disorders, obese and diabetic patients and mice present an alteration of ENS neurons which has repercussions on colonic and duodenal contraction. Here, the duodenal hyper-contractility is associated with a significant increase of glucose absorption, and with a dysfunction of the gut-brain axis which favor an insulin resistant state (12). Nowadays, therapeutic strategies have just started to focus their attention on the impact of oral bioactive peptides to treat hyperglycemia and insulin resistance in diabetic patients (61). Recently, we have discovered that the chronic oral gavage of apelin in diabetic mice improves glucose tolerance and insulin sensitivity in skeletal muscle (12). At this high dose, apelin can stimulate the activity of duodenal nNOS neurons (1) first, to decrease glucose absorption by a "local" action and (2) second, to restore the gut-brain axis and then insulin sensitivity (12). Of course, apelin is now considered as an interesting potential candidate to treat type 2 diabetes via this novel mode of injection i.e., per os and/or by intravenous injection (61).

As opposed to apelin which could have a potential negative effect in the brain (62), another gut peptide candidate is well described in the literature. Galanin is a gut peptide that is also known as a neurotransmitter in the hypothalamus. Intracerebroventricular and i.v. injection of galanin in mice improve glucose homeostasis, and in particular insulin sensitivity (63-65). In the gut, the level of galanin is significantly decreased in the duodenum during type 2 diabetes (66). Recently, Abot et al. have discovered that chronic oral galanin treatment in diabetic mice have significantly improved glucose tolerance (16). Here, oral galanin is able to increase the release of enteric NO in the duodenum to restore the gut-brain axis similar to that previously observed with apelin. Finally, the improvement of glucose metabolism is associated with a significant increase of glucose entry in muscle, liver and adipose tissue.

How could the gut peptide reach the ENS and how can we use them as potential anti-diabetic drugs? Whether or not other mode of transport could exist in the intestine for these peptides is not characterized. The mechanisms used by luminal peptide to join the ENS neurons are not well described. Like that observed with leptin (19), apelin could reach the ENS via transcytosis. In a pharmacological point of view, peptides given orally must be active only in the duodenum to limit potential "indesirable" effect. For example, oral peptides could have a significant impact on gastric emptying and these could have consequences on digestion and/or food intake. 


\section{PEPTIDES/ENS AND FOOD INTAKE}

As discussed earlier in this review, the regulation of food intake is a complex and tightly regulated system requiring the integration of local (i.e., intestinal, ENS) signals and distal signals (i.e., in the brain). As resume recently by Prinz and Stengel (67), numerous gut peptides are able to control food intake. These peptides may exert anorexigenic (GLP-1, PPY, and CCK) or orexigenic (Ghrelin) effects by acting directly in the brain or by using an afferent vagal pathway. As these modes of action of gut peptides are well described in the literature and potentially do not require the ENS, we have decided to focus our attention on more recent concepts showing interactions between gut peptides, intestinal actors (epithelial and endocrine cells, enteric neurons, and microbiota), and food intake.

The role of the endogenous production of glucose by the intestinal epithelial cells may constitute a major mechanism by which nutrients regulate food intake. Several studies led by Pr. Mithieux and his team have elegantly demonstrated that the so called, intestinal gluconeogenesis (IGN), is a key process promoting a decrease of hunger but also an improvement of insulin sensitivity while the liver is decreasing is endogenous glucose production (68). IGN is a process that has been shown to be activated by the degradation of dietary proteins in amino acids (69). Interestingly, the same team has found that mice deficient of the key enzyme involved in the IGN (i.e., glucose-6 phosphatase) exhibit increased basal sympathetic tone but also develop hypothalamic resistance to leptin, suggesting again a key link with the regulation of food intake and energy homeostasis.

Remarkably, IGN is massively induced after metabolic surgery and can finally account for up to $20 \%$ of the total endogenous glucose production in post-absorptive state (70). It is worth noting that metabolic surgery (e.g., RYGB) is associated with a dramatic change in the route of the food nutrients and therefore may directly affect the gut microbiota composition (71). Gastric bypass is also characterized by a massive increase in gut peptides involved in food intake and glucose metabolism such as GLP-1 and PYY (72). This phenomenon can probably be attributed in part to the direct contact between nutrients (i.e., glucose, lipids, and amino acids) and EECs producing those hormones but also via the fermentation of non-digested food components and nutrients by the gut microbiota. One of the key examples linking the fermentation of fibers and the secretion of GLP-1 has been published many years before. Indeed, it has been clearly demonstrated that the mechanisms by which specific dietary fibers such as prebiotics (i.e., inulin, oligofructose) reduces glycemia, food intake and improves insulin sensitivity directly rely on the production of the gut peptide GLP-1 $(73,74)$. More recently, it has been shown that the metabolites produced by gut bacteria, such

\section{REFERENCES}

1. Furness JB. The enteric nervous system and neurogastroenterology. Nat Rev Gastroenterol Hepatol (2012) 9:286-94. doi:10.1038/nrgastro. 2012.32

2. Sababi M, Bengtsson UH. Enhanced intestinal motility influences absorption in anaesthetized rat. Acta Physiol Scand (2001) 172:115-22. doi:10.1046/j. 1365-201X.2001.00849.x as the SCFAs butyrate and propionate, likely contribute to the modulation of the production of both GLP-1 and PYY in these conditions (75) (Figure 1).

It is important to note that all the aforementioned mechanisms, such as the IGN, the bacterial fermentation (i.e., SCFAs), or the gut peptides production, are connected to the ENS. For example, in the case of the fermentation of fibers, the generated compound propionate has been shown to bind to GPR-41 expressed in the nerve endings of the portal vein wall. But it has also been discovered that propionate production by microbes also controls IGN and eventually food intake (76) (Figure 1).

Finally, this last example clearly shows that all these interesting mechanisms are intertwined. Indeed, a recent study shows that VIP induces glucose- 6 phosphatase activity and eventually IGN in vivo. VIP neurons innervate the gut epithelium, in addition, in this study the authors suggest that VIP is also important for the bacterial metabolite propionate-induced activation of IGN. Thus, because VIP is expressed in neurons present in submucosal and myenteric plexuses, and is modulated by the microbiota derived compounds produced by the fermentation. These findings also suggest that it exist a local release of VIP by enteric neurons which may be a key mechanism by which nutrients, peptides, and microbial metabolites are finally involved in the activation of IGN and thus control food intake and glucose metabolism (77).

\section{SUMMARY/CONCLUSION}

Intestinal bioactive peptides by acting on ENS neurons represent a potential therapeutic target to treat metabolic and food disorders associated with type 2 diabetes and obesity. Their origins, i.e., bacterial and/or intestinal wall facilitates their utilization for oral treatment. Whether their use alone or in combination with pre- and probiotics for therapeutic strategies will be tested in the future. Thus, the study of the gut-brain axis is only at the beginning of its story, and bioactive peptides represent one, but not the least, of the way forward to treat multiple diseases.

\section{AUTHOR CONTRIBUTIONS}

All authors listed have made a substantial, direct, and intellectual contribution to the work and approved it for publication.

\section{ACKNOWLEDGMENTS}

PC is senior research associate of the FRS-FNRS (Fonds de la Recherche Scientifique, Belgium) and received grants from WELBIO-CGR-2017-C2, Funds Baillet Latour and ERC Starting Grant 2013 (336452-ENIGMO).

3. Furness JB, Kunze WA, Bertrand PP, Clerc N, Bornstein JC. Intrinsic primary afferent neurons of the intestine. Prog Neurobiol (1998) 54:1-18. doi:10.1016/ S0301-0082(97)00051-8

4. Spencer NJ, Smith TK. Mechanosensory S-neurons rather than AH-neurons appear to generate a rhythmic motor pattern in guinea-pig distal colon. J Physiol (2004) 558:577-96. doi:10.1113/jphysiol.2004.063586

5. Mazzuoli G, Schemann M. Multifunctional rapidly adapting mechanosensitive enteric neurons (RAMEN) in the myenteric plexus of the guinea 
pig ileum. J Physiol (2009) 587:4681-94. doi:10.1113/jphysiol.2009. 177105

6. Kunze WA, Furness JB. The enteric nervous system and regulation of intestinal motility. Annu Rev Physiol (1999) 61:117-42. doi:10.1146/annurev. physiol.61.1.117

7. Gallego D, Mane N, Gil V, Martinez-Cutillas M, Jimenez M. Mechanisms responsible for neuromuscular relaxation in the gastrointestinal tract. Rev Esp Enferm Dig (2016) 108:721-31. doi:10.17235/reed.2016.4058/2015

8. Neunlist M, Schemann M. Nutrient-induced changes in the phenotype and function of the enteric nervous system. J Physiol (2014) 592:2959-65. doi:10.1113/jphysiol.2014.272948

9. Furness JB, Rivera LR, Cho HJ, Bravo DM, Callaghan B. The gut as a sensory organ. Nat Rev Gastroenterol Hepatol (2013) 10:729-40. doi:10.1038/ nrgastro.2013.180

10. Schwartz MW, Porte D Jr. Diabetes, obesity, and the brain. Science (2005) 307:375-9. doi:10.1126/science.1104344

11. Cote CD, Zadeh-Tahmasebi M, Rasmussen BA, Duca FA, Lam TK. Hormonal signaling in the gut. J Biol Chem (2014) 289:11642-9. doi:10.1074/jbc.O114. 556068

12. Fournel A, Drougard A, Duparc T, Marlin A, Brierley SM, Castro J, et al. Apelin targets gut contraction to control glucose metabolism via the brain. Gut (2017) 66:258-69. doi:10.1136/gutinl-2015-310230

13. Chandrasekharan B, Srinivasan S. Diabetes and the enteric nervous system. Neurogastroenterol Motil (2007) 19(12):951-60.

14. Yarandi SS, Srinivasan S. Diabetic gastrointestinal motility disorders and the role of enteric nervous system: current status and future directions. Neurogastroenterol Motil (2014) 26:611-24. doi:10.1111/nmo.12330

15. Stenkamp-Strahm CM, Kappmeyer AJ, Schmalz JT, Gericke M, Balemba O. High-fat diet ingestion correlates with neuropathy in the duodenum myenteric plexus of obese mice with symptoms of type 2 diabetes. Cell Tissue Res (2013) 354:381-94. doi:10.1007/s00441-013-1681-z

16. Abot A, Lucas A, Bautzova T, Bessac A, Fournel A, Le-Gonidec S, et al. Galanin enhances systemic glucose metabolism through enteric nitric oxide synthase-expressed neurons. Mol Metab (2018) 10:100-8. doi:10.1016/j. molmet.2018.01.020

17. Stenkamp-Strahm CM, Nyavor YE, Kappmeyer AJ, Horton S, Gericke M, Balemba OB. Prolonged high fat diet ingestion, obesity, and type 2 diabetes symptoms correlate with phenotypic plasticity in myenteric neurons and nerve damage in the mouse duodenum. Cell Tissue Res (2015) 361:411-26. doi:10.1007/s00441-015-2132-9

18. Reichardt F, Baudry C, Gruber L, Mazzuoli G, Moriez R, Scherling C, et al. Properties of myenteric neurones and mucosal functions in the distal colon of diet-induced obese mice. J Physiol (2013) 591:5125-39. doi:10.1113/jphysiol. 2013.262733

19. Cammisotto PG, Gingras D, Bendayan M. Transcytosis of gastric leptin through the rat duodenal mucosa. Am J Physiol Gastrointest Liver Physiol (2007) 293:G773-9. doi:10.1152/ajpgi.00260.2007

20. Amato A, Cinci L, Rotondo A, Serio R, Faussone-Pellegrini MS, Vannucchi MG, et al. Peripheral motor action of glucagon-like peptide- 1 through enteric neuronal receptors. Neurogastroenterol Motil (2010) 22:664-e203. doi:10.1111/j. 1365-2982.2010.01476.x

21. Rotondo A, Amato A, Lentini L, Baldassano S, Mule F. Glucagon-like peptide-1 relaxes gastric antrum through nitric oxide in mice. Peptides (2011) 32:60-4. doi:10.1016/j.peptides.2010.09.028

22. Voss U, Sand E, Hellstrom PM, Ekblad E. Glucagon-like peptides 1 and 2 and vasoactive intestinal peptide are neuroprotective on cultured and mast cell co-cultured rat myenteric neurons. BMC Gastroenterol (2012) 12:30. doi:10.1186/1471-230X-12-30

23. Sigalet DL, Wallace LE, Holst JJ, Martin GR, Kaji T, Tanaka H, et al. Enteric neural pathways mediate the anti-inflammatory actions of glucagon-like peptide 2. Am J Physiol Gastrointest Liver Physiol (2007) 293:G211-21. doi:10.1152/ajpgi.00530.2006

24. Sigalet DL, Wallace L, De Heuval E, Sharkey KA. The effects of glucagon-like peptide 2 on enteric neurons in intestinal inflammation. Neurogastroenterol Motil (2010) 22(12):1318-e350. doi:10.1111/j.1365-2982.2010.01585.x

25. Ellis M, Chambers JD, Gwynne RM, Bornstein JC. Serotonin and cholecystokinin mediate nutrient-induced segmentation in guinea pig small intestine. Am J Physiol Gastrointest Liver Physiol (2013) 304:G749-61. doi:10.1152/ ajpgi.00358.2012
26. Lv Y, Feng M, Che T, Sun H, Luo Y, Liu K, et al. CCK mediated the inhibitory effect of oxytocin on the contraction of longitudinal muscle strips of duodenum in male rats. Pflugers Arch (2010) 460:1063-71. doi:10.1007/ s00424-010-0880-7

27. Tack J, Depoortere I, Bisschops R, Delporte C, Coulie B, Meulemans A, et al. Influence of ghrelin on interdigestive gastrointestinal motility in humans. Gut (2006) 55:327-33. doi:10.1136/gut.2004.060426

28. Fujino K, Inui A, Asakawa A, Kihara N, Fujimura M, Fujimiya M. Ghrelin induces fasted motor activity of the gastrointestinal tract in conscious fed rats. J Physiol (2003) 550:227-40. doi:10.1113/jphysiol.2003.040600

29. Taniguchi H, Ariga H, Zheng J, Ludwig K, Takahashi T. Effects of ghrelin on interdigestive contractions of the rat gastrointestinal tract. World J Gastroenterol (2008) 14:6299-302. doi:10.3748/wjg.14.6299

30. Edholm T, Levin F, Hellstrom PM, Schmidt PT. Ghrelin stimulates motility in the small intestine of rats through intrinsic cholinergic neurons. Regul Pept (2004) 121:25-30. doi:10.1016/j.regpep.2004.04.001

31. Yang CG, Liao ZF, Qiu WC, Yan J, Wang ZG. Function of ghrelin and ghrelin receptors in the network regulation of gastric motility. Mol Med Rep (2014) 10:2453-8. doi:10.3892/mmr.2014.2571

32. Florian V, Caroline F, Francis C, Camille S, Fabielle A. Leptin modulates enteric neurotransmission in the rat proximal colon: an in vitro study. Regul Pept (2013) 185:73-8. doi:10.1016/j.regpep.2013.06.010

33. Browning KN, Lees GM. Inhibitory effects of NPY on ganglionic transmission in myenteric neurones of the guinea-pig descending colon. Neurogastroenterol Motil (2000) 12:33-41. doi:10.1046/j.1365-2982.2000.00178.x

34. Wang L, Gourcerol G, Yuan PQ, Wu SV, Million M, Larauche M, et al. Peripheral peptide YY inhibits propulsive colonic motor function through Y2 receptor in conscious mice. Am J Physiol Gastrointest Liver Physiol (2010) 298: G45-56. doi:10.1152/ajpgi.00349.2009

35. Amato A, Baldassano S, Caldara GF, Mule F. Pancreatic polypeptide stimulates mouse gastric motor activity through peripheral neural mechanisms. Neurogastroenterol Motil (2017) 29:(1). doi:10.1111/nmo.12901

36. Newman KD, Mhalhal TR, Washington MC, Heath JC, Sayegh AI. Peptide tyrosine tyrosine 3-36 reduces meal size and activates the enteric neurons in male Sprague-Dawley rats. Dig Dis Sci (2017) 62:3350-8. doi:10.1007/ s10620-017-4788-3

37. Wheway J, Mackay CR, Newton RA, Sainsbury A, Boey D, Herzog H, et al. A fundamental bimodal role for neuropeptide Y1 receptor in the immune system. J Exp Med (2005) 202(11):1527-38. doi:10.1084/jem.20051971

38. Chandrasekharan B, Bala V, Kolachala VL, Vijay-Kumar M, Jones D, Gewirtz AT, et al. Targeted deletion of neuropeptide Y (NPY) modulates experimental colitis. PLoS One (2008) 3(10):e3304. doi:10.1371/journal.pone. 0003304

39. Chandrasekharan B, Nezami BG, Srinivasan S. Emerging neuropeptide targets in inflammation: NPY and VIP. Am J Physiol Gastrointest Liver Physiol (2013) 304(11):G949-57. doi:10.1152/ajpgi.00493.2012

40. Arciszewski MB, Ekblad E. Effects of vasoactive intestinal peptide and galanin on survival of cultured porcine myenteric neurons. Regul Pept (2005) 125:185-92. doi:10.1016/j.regpep.2004.08.036

41. Psichas A, Reimann F, Gribble FM. Gut chemosensing mechanisms. J Clin Invest (2015) 125:908-17. doi:10.1172/JCI76309

42. Gribble FM, Reimann F. Enteroendocrine cells: chemosensors in the intestinal epithelium. Annu Rev Physiol (2016) 78:277-99. doi:10.1146/ annurev-physiol-021115-105439

43. Sandoval DA, D'Alessio DA. Physiology of proglucagon peptides: role of glucagon and GLP-1 in health and disease. Physiol Rev (2015) 95:513-48. doi:10.1152/physrev.00013.2014

44. Plovier H, Cani PD. Enteroendocrine cells: metabolic relays between microbes and their host. Endocr Dev (2017) 32:139-64. doi:10.1159/000475736

45. Drucker DJ. Deciphering metabolic messages from the gut drives therapeutic innovation: the 2014 Banting Lecture. Diabetes (2015) 64:317-26. doi:10.2337/ $\mathrm{db} 14-1514$

46. Knauf C, Cani PD, Perrin C, Iglesias MA, Maury JF, Bernard E, et al. Brain glucagon-like peptide- 1 increases insulin secretion and muscle insulin resistance to favor hepatic glycogen storage. J Clin Invest (2005) 115:3554-63. doi:10.1172/JCI25764

47. Sun EW, de Fontgalland D, Rabbitt P, Hollington P, Sposato L, Due SL, et al. Mechanisms controlling glucose-induced GLP-1 secretion in human small intestine. Diabetes (2017) 66:2144-9. doi:10.2337/db17-0058 
48. Sigalet DL. Nonruminant nutrition symposium: the role of glucagon-like peptide-2 in controlling intestinal function in human infants: regulator or bystander? J Anim Sci (2012) 90:1224-32. doi:10.2527/jas. 2011-4704

49. Pathak V, Flatt PR, Irwin N. Cholecystokinin (CCK) and related adjunct peptide therapies for the treatment of obesity and type 2 diabetes. Peptides (2018) 100:229-35. doi:10.1016/j.peptides.2017.09.007

50. van der Lely AJ, Tschop M, Heiman ML, Ghigo E. Biological, physiological, pathophysiological, and pharmacological aspects of ghrelin. Endocr Rev (2004) 25:426-57. doi:10.1210/er.2002-0029

51. Castan-Laurell I, Dray C, Knauf C, Kunduzova O, Valet P. Apelin, a promising target for type 2 diabetes treatment? Trends Endocrinol Metab (2012) 23:234-41. doi:10.1016/j.tem.2012.02.005

52. Dray C, Sakar Y, Vinel C, Daviaud D, Masri B, Garrigues L, et al. The intestinal glucose-apelin cycle controls carbohydrate absorption in mice. Gastroenterology (2013) 144:771-80. doi:10.1053/j.gastro.2013.01.004

53. Jackerott M, Larsson LI. Immunocytochemical localization of the NPY/ PYY Y1 receptor in enteric neurons, endothelial cells, and endocrine-like cells of the rat intestinal tract. J Histochem Cytochem (1997) 45:1643-50. doi:10.1177/002215549704501207

54. Belai A, Calcutt NA, Carrington AL, Diemel LT, Tomlinson DR, Burnstock G. Enteric neuropeptides in streptozotocin-diabetic rats; effects of insulin and aldose reductase inhibition. J Auton Nerv Syst (1996) 58:163-9. doi:10.1016/ 0165-1838(95)00129-8

55. Lang R, Gundlach AL, Holmes FE, Hobson SA, Wynick D, Hokfelt T, et al. Physiology, signaling, and pharmacology of galanin peptides and receptors: three decades of emerging diversity. Pharmacol Rev (2015) 67:118-75. doi:10.1124/pr.112.006536

56. McVey Neufeld KA, Mao YK, Bienenstock J, Foster JA, Kunze WA. The microbiome is essential for normal gut intrinsic primary afferent neuron excitability in the mouse. Neurogastroenterol Motil (2013) 25:183-e88. doi:10.1111/ nmo.12049

57. McVey Neufeld KA, Perez-Burgos A, Mao YK, Bienenstock J, Kunze WA. The gut microbiome restores intrinsic and extrinsic nerve function in germfree mice accompanied by changes in calbindin. Neurogastroenterol Motil (2015) 27:627-36. doi:10.1111/nmo.12534

58. Martin AM, Young RL, Leong L, Rogers GB, Spencer NJ, Jessup CF, et al. The diverse metabolic roles of peripheral serotonin. Endocrinology (2017) 158:1049-63. doi:10.1210/en.2016-1839

59. Bufe B, Zufall $\mathrm{F}$. The sensing of bacteria: emerging principles for the detection of signal sequences by formyl peptide receptors. Biomol Concepts (2016) 7:205-14. doi:10.1515/bmc-2016-0013

60. Cianciulli A, Acquafredda A, Cavallo P, Saponaro C, Calvello R, Mitolo V, et al. f-Met-Leu-Phe stimulates nitric oxide production in chick embryo neurons: the role of NF-kB. Immunopharmacol Immunotoxicol (2009) 31:51-63. doi:10.1080/08923970802338799

61. Weber C. Neurogastroenterology: improving glucose tolerance via the gut-brain axis. Nat Rev Gastroenterol Hepatol (2016) 13(1):4. doi:10.1038/ nrgastro.2015.204

62. Drougard A, Duparc T, Brenachot X, Carneiro L, Gouaze A, Fournel A, et al. Hypothalamic apelin/reactive oxygen species signaling controls hepatic glucose metabolism in the onset of diabetes. Antioxid Redox Signal (2014) 20:557-73. doi:10.1089/ars.2013.5182

63. Fang P, Yu M, Shi M, Zhang Z, Sui Y, Guo L, et al. Galanin peptide family as a modulating target for contribution to metabolic syndrome. Gen Comp Endocrinol (2012) 179:115-20. doi:10.1016/j.ygcen.2012.07.029

64. Fang P, Yu M, Shi M, He B, Zhang Z, Bo P. The neuropeptide galanin benefits insulin sensitivity in subjects with type 2 diabetes. Curr Protein Pept Sci (2013) 14:669-73. doi:10.2174/1389203711209070611
65. Fang PH, Yu M, Ma YP, Li J, Sui YM, Shi MY. Central nervous system regulation of food intake and energy expenditure: role of galanin-mediated feeding behavior. Neurosci Bull (2011) 27:407-12. doi:10.1007/s12264011-1841-7

66. Spangeus A, El-Salhy M. Myenteric plexus of obese diabetic mice (an animal model of human type 2 diabetes). Histol Histopathol (2001) 16:159-65. doi:10.14670/HH-16.159

67. Prinz P, Stengel A. Control of food intake by gastrointestinal peptides: mechanisms of action and possible modulation in the treatment of obesity. J Neurogastroenterol Motil (2017) 23:180-96. doi:10.5056/jnm16194

68. Soty M, Gautier-Stein A, Rajas F, Mithieux G. Gut-brain glucose signaling in energy homeostasis. Cell Metab (2017) 25:1231-42. doi:10.1016/j.cmet. 2017.04.032

69. Mithieux G, Misery P, Magnan C, Pillot B, Gautier-Stein A, Bernard C, et al. Portal sensing of intestinal gluconeogenesis is a mechanistic link in the diminution of food intake induced by diet protein. Cell Metab (2005) 2:321-9. doi:10.1016/j.cmet.2005.09.010

70. Troy S, Soty M, Ribeiro L, Laval L, Migrenne S, Fioramonti X, et al. Intestinal gluconeogenesis is a key factor for early metabolic changes after gastric bypass but not after gastric lap-band in mice. Cell Metab (2008) 8:201-11. doi:10.1016/j.cmet.2008.08.008

71. Li JV, Ashrafian H, Bueter M, Kinross J, Sands C, le Roux CW, et al. Metabolic surgery profoundly influences gut microbial-host metabolic cross-talk. Gut (2011) 60:1214-23. doi:10.1136/gut.2010.234708

72. Hutch CR, Sandoval D. The role of GLP-1 in the metabolic success of bariatric surgery. Endocrinology (2017) 158:4139-51. doi:10.1210/en.201700564

73. Cani PD, Knauf C, Iglesias MA, Drucker DJ, Delzenne NM, Burcelin R. Improvement of glucose tolerance and hepatic insulin sensitivity by oligofructose requires a functional glucagon-like peptide 1 receptor. Diabetes (2006) 55:1484-90. doi:10.2337/db05-1360

74. Cani PD, Dewever C, Delzenne NM. Inulin-type fructans modulate gastrointestinal peptides involved in appetite regulation (glucagon-like peptide-1 and ghrelin) in rats. Br J Nutr (2004) 92:521-6. doi:10.1079/BJN20041225

75. Brooks L, Viardot A, Tsakmaki A, Stolarczyk E, Howard JK, Cani PD, et al. Fermentable carbohydrate stimulates FFAR2-dependent colonic PYY cell expansion to increase satiety. Mol Metab (2017) 6:48-60. doi:10.1016/j. molmet.2016.10.011

76. De Vadder F, Kovatcheva-Datchary P, Goncalves D, Vinera J, Zitoun C, Duchampt A, et al. Microbiota-generated metabolites promote metabolic benefits via gut-brain neural circuits. Cell (2014) 156:84-96. doi:10.1016/j. cell.2013.12.016

77. De Vadder F, Plessier F, Gautier-Stein A, Mithieux G. Vasoactive intestinal peptide is a local mediator in a gut-brain neural axis activating intestinal gluconeogenesis. Neurogastroenterol Motil (2015) 27:443-8. doi:10.1111/ nmo. 12508

Conflict of Interest Statement: The authors declare that the research was conducted in the absence of any commercial or financial relationships that could be construed as a potential conflict of interest.

Copyright (c) 2018 Abot, Cani and Knauf. This is an open-access article distributed under the terms of the Creative Commons Attribution License (CC BY). The use, distribution or reproduction in other forums is permitted, provided the original author(s) and the copyright owner are credited and that the original publication in this journal is cited, in accordance with accepted academic practice. No use, distribution or reproduction is permitted which does not comply with these terms. 